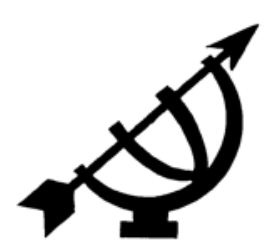

\title{
Religion in education: is there yet another solution?
}

\author{
J.L. van der Walt \\ Faculty of Education Sciences \\ Potchefstroom Campus \\ North-West University \\ POTCHEFSTROOM \\ E-mail: jlvdwalt@aerosat.co.za
}

\begin{abstract}
Religion in education: is there yet another solution?

As colleague and co-worker of Professor Bennie van der Walt, the author has been in a position for several decades now to apply some of Bennie van der Walt's philosophical and theological insights in the field of education. Professor Van der Walt's recent discussion and critique of secularism and of religious tolerance enables the author to analyse the educational situation in South Africa and elsewhere with particular emphasis on policies about religion in/and education. These investigations lead him to conclude that most education systems seem to resort to secular public-private and worldly-sacral dualistic policies for addressing the problem of potential religious conflict in schools. After considering the Dutch policy of (increasing) pillarisation and the South African policy of banning confessional aspects of religious education to the private spheres of citizens' lives, he proposes a solution based on the concept of institutional religious and life-conceptual identity. This approach can also lead to religious tolerance among learners in schools (as mooted by Bennie van der Walt and others) while circumventing the pitfalls of secularism.
\end{abstract}

\section{Opsomming}

Godsdiens in die onderwys: is daar nie tog 'n ander oplossing nie?

As kollega en medewerker van professor Bennie van der Walt was dit vir die outeur verskeie dekades lank moontlik om sommige van Bennie van der Walt se filosofiese en teologiese 
insigte op die terrein van die onderwys toe te pas. Professor van der Walt se onlangse bespreking en ontleding van sekularisme en godsdienstige verdraagsaamheid stel die outeur in staat om die onderwyssituasie in Suid-Afrika en elders te ontleed, met besondere nadruk op beleid rakende godsdiens in die onderwys/die skole. Hierdie ondersoek lei hom tot die gevolgtrekking dat die meeste onderwysstelsels terugval op sekularistiese openbaar-privaat en wêreldse-heilige (sakrale) dualistiese beleide om die probleem van potensiële religieuse konflik in skole te voorkom. Na 'n oorweging van die Nederlandse beleid van (toenemende) versuiling en van die SuidAfrikaanse beleid om die konfessionele aspekte van godsdiensonderwys na die private sfere van mense se lewens te verban, doen hy aan die hand dat 'n nuwe beleid geskep moet word wat op die idee van institusionele godsdienstige en lewensbeskoulike identiteit gebaseer is. Hierdie oplossing kan ook tot godsdienstige verdraagsaamheid onder leerders in skole lei (soos deur Bennie van der Walt en andere in die vooruitsig gestel), terwyl dit die voetangels van die sekularisme ontduik.

\section{Introduction}

Since my appointment as a lecturer in Education at the former Potchefstroom University for Christian Higher Education in 1975, I have enjoyed the privilege of working closely with Professor Bennie van der Walt. At that time, he was the Director of the Institute for Reformational Studies (IRS). Soon after my move to a lectureship in Philosophy of Education in 1976, I was drawn into the activities of the IRS, and remained involved until I took leave of my office as Dean of the Faculty of Education at the end of 2000. Together with Van der Walt and the other members of the Board of the IRS (and all of its successors) I experienced all the successes, trials and tribulations of that Institute. As a Board member I was aware of the valuable work done by Van der Walt and his staff in the interest of the advancement of Christian scholarship in general, and particularly in Africa. I kept abreast of his work also after my move to Port Elizabeth in 2001 (as a staff member of the "new" North-West University). Bennie has always been a prolific writer, and has kept up that reputation even after his retirement. In recent years, he has been publishing a succession of scholarly articles, and also the occasional book.

I have always found Bennie's theological-philosophical publications useful for my work in education. Since his insights have always been readily transposable to other scholarly fields, many of them served as fundamental ("principial") pointers for education (both in the 
sense of schooling/teaching-learning and "up-bringing"). During my own career, I have made extensive (implicit as well as explicit) use of his philosophical views (along with those of other reformational thinkers).

For the purposes of this article, I found his series of three articles in recent volumes of the Journal for Christian scholarship on secularism and his ideas on religious tolerance of great import. I was glad to find that he had included these articles on secularism in his book Transforming power: challenging contemporary secular society (Van der Walt, B.J. 2007:221-296). His depiction and critique of secularism are useful for coming to grips with the situation in post-1994 South Africa. In his discussion he takes the views of De Knijff, Dekker and Tennekes (1992) and others about secularism somewhat further. His critique of secularism is one of the most exhaustive and penetrative that I am aware of. But let me first outline the problem that this article deals with.

\section{The problem}

In pre-1994 South Africa, approximately 85\% of the population regarded itself as adhering to the Christian faith, living according to a Christian life- and worldview, and subject to church hegemony. This religious majority tacitly condoned the apartheid government's Christian approach, and non-Christian minorities were either tolerated, or their voices disregarded (cf. Behr, 1984:27-28; Schutte, 1984:36-37; Wnuk-Lipinski \& Fuchs, 2006:41-42).

As far as education was concerned, pre-1994 South Africa could not be regarded as a secular society, in other words a society in which life is dualistically divided into public and private domains - with religion confined only to the private realm (Van der Walt, B.J., 2007:265). The National Education Policy Act (Act 39 of 1967) stipulated that school education for whites would be Christian in warp and woof. Similar Acts for black, coloured and Indian education were in force up to 1996 (Behr, 1984:163 ff.). The National Party apartheid government (1948-1994) enjoyed sufficient support within the white community (at least for the first three to four decades of its time in power) for persisting with Act 39 of 1967, although the implementation of the Act had to be adapted frequently to meet the demands of the swiftly changing political situation, especially from 1976 onwards.

With the advent of democratic government in South Africa in 1994, everything changed. A major change as far as education was con- 
cerned, was the removal of enforced Christian education in public (state) schools. If one understands the term secular in terms of Sinclair's (1999:1342) definition, namely as relating to worldly as opposed to sacred things, not concerned with or related to religion, not within the control of the church, (with regard to education, etc.) having no particular religious affinity, then it is possible to say that the post-1994 statutory changes constituted a step in the direction of secularism. The umbilical cord between public education and Christianity in general, and the Christian churches in particular, was cut in the process of the post-1996 overhaul of education in South Africa.

Only one aspect of school education remained unresolved at that time, namely religious/religion education in schools. After long deliberation and consultation, a Policy on Religion was promulgated only in 2003. In the Preamble to the Policy, the then Minister of Education (Kader Asmal) averred that South Africa was not a secular state, because Government accepted that religion had a role to play in the (public) schools. In view of this, Government opted for a co-operative model between state (public education) and religion/ religious institutions. However, analysis of the Policy reveals that only religious observances and Religion Studies (a scientific/academic school subject) would enjoy a place in public schools, but not confessional religious education. The latter was regarded as pertaining to the parental home and to the respective religious denominations - not the public or state school. The fact that particularly the confessional aspects of religious education were relegated to the private realm can be regarded as a step towards secularism.

Sinclair (referred to above) and the Minister of Education, Asmal, seem to hold a different view of secularism than, for instance, Bennie van der Walt and Stuart Fowler. For Asmal, the fact that Government sees a place for an academic subject like Religious Studies and for religious observances in schools serves as proof that the official approach is not secularist. In his opinion, the fact that confessional religious education is relegated to the private sphere of parental homes and churches (mosques, temples, synagogues) does not detract from this truth. Fowler does not agree with this, and Van der Walt goes so far as to regard secularism as a new religion bent on ousting the Christian religion from the public sphere, among others the public schools. According to Fowler (2001:132)

[t]he definite feature of secularism is not the denial of God or of the sacred but the separation of the secular and the sacred, of everyday knowledge and religious faith. Secularism does not 
banish all belief in God. It recognizes the validity of religious faith as a legitimate option for the individual but assigns this faith to a spiritual sphere of human experience separate from the secular sphere of everyday affairs. It makes belief and disbelief in God equally irrelevant to the practice of everyday life - in agriculture and farming, in politics, in commerce and industry, in sports and recreation and in academic disciplines other than theology. In these areas, autonomous human authority reigns supreme.

Van der Walt (B.J., 2007:233) sees secularism as a religion in its own right, one that aims at replacing Christianity in all walks of life.

... faith (in the broader sense of all-encompassing religion) is not limited to the church and cannot be. Whether secularism is willing to recognise it or not, our religious orientation determines our total life, because God created us as religious beings ... secularism itself would like to be much more than merely restricting religion to private life. It pursues the ideal (at least in the public field) of being the dominant faith.

These two definitions of secularism differ from that of the Minister. It is, however, possible that the Minister was merely sugaring the secularist pill for the adherents of mainstream religions in South Africa, including the Christians. Whatever the case, Chopra (2009:189) draws a clear line between the position of the Minister on the one hand, and that of Fowler and Van der Walt on the other:

On the one hand, we have the secular world and the rule of law. On the other hand, we have the Christian world and the rule of God.

This brings us to the crux of the problem. With respect to religion in education, on which side of the line should Christian educators take a stand? How should confessional religion education be approached in a democracy? Should it, in secularist phraseology, be regarded as a "private matter", i.e. an aspect of education that does not belong in the public sphere such as a public school, but rather to the "private sphere" of the parental home and the particular religious denomination? Should it be brought into the public sphere by making use of a mechanism like pillarisation, such as we find in the Nether- 
lands? Or is there yet another way of resolving the problem of religion in education? 1

This is not a fictitious or academic problem. Certain scholars (educationists) ${ }^{2}$ have positioned themselves in favour of the rule of law, and resultantly insisted that the Minister of Education was correct in banning confessional religion to the private sphere of parental home and church (cf. Roux, 2003; 2006a; 2006b; Ferguson \& Roux, 2004; Roux \& Du Preez, 2005). They insist that the Policy (2003) is not only correct, but should be conscientiously applied for promoting secular values such as democracy, religious tolerance and diversity literacy. Other Christian educationists have positioned themselves on the side of the rule of God, convinced that his rule cannot be restricted to only the private spheres of people's lives but should be recognised and confessed also in the public sphere, including the public or state schools (cf. Fowler, 1991:79-80; Abdool et al., 2007; De Klerk-Luttig \& Van der Walt, 2008; Valenkamp, 2008; Van der Walt et al., 2008; Wolhuter et al., 2009).

In the rest of this article, I shall approach this problem from several perspectives. After looking at how the problem has been approached in some other countries, and in South Africa since 2003, with reference to the respective philosophies behind the different stances, I explore the possibilities of finding another solution to the conundrum of religion in/and education (schooling).

\section{Two European solutions}

Since 1917, the Dutch system has been making provision for institutions associated or affiliated with the various religious denominations to openly and freely function as if they were public institutions. A long struggle during the eighteenth century for the socalled religious and life-conceptual freedom of education and

1 A debate about whether confessional religious instruction should be included in the formal curricula of schools or not has been raging in South Africa since the promulgation of the Policy in 2003 . The debate has typically taken two forms. On the one hand, educational law experts have been debating whether the stipulations of the Policy could be reconciled with stipulations in the Constitution as well as the South African School Act, both of 1996. On the other hand, philosophers of education and theologians have been debating the advantages and the disadvantages of the inclusion of confessional religious instruction in public schools. Kruger (2009) gives an excellent overview of the latter debate in the popular press.

2 Among them self-declared Christians or those with a Christian background. 
schooling led to the promulgation of Section 194 on education in the Constitution of 1848. This Section (Section 192 in the 1917 Constitution, now Section 23 in the 1983 Constitution) is still in force today. According to Sub-section 23.1, the state is responsible for the provision of education to all; education is a basic social right. Subsection 23.2 stipulates education/schooling to be "free"; in other words, parents and school communities possess the freedom and right to choose for themselves education (schooling) that is in agreement with their own religious and social orientation. The state retains supervision of such "particular" or "private" schools, the teachers there must be competent and show proper conduct. Section 23.3 stipulates much the same for public schools. Even these schools are expected to "respect the religious or life-conceptual convictions of everyone involved". Sub-section 23.7 stipulates that particular or private education/schooling that complies with the stipulations of the Act "will be funded by the public treasury based on the same norms as for public schools". In other words, particular or private institutions and public or state institutions are being equitably funded by the state (Förrer \& Van Hardeveld, 1992:23). According to the Constitution, parents, communities and their schools enjoy three forms of freedom: freedom of religious and lifeconceptual direction, freedom of institution (such as a school, college or university) and freedom of setting up and managing an institution (learning method, appointment of staff, management, the role of parents and other stakeholders, religious education, finances and so on) (Förrer \& Van Hardeveld, 1992:26).

A group of like-minded institutions, in other words institutions that share the same religious or lifeview identity, forms a particular "identity pillar" and can consist of schools, higher education institutions, educational and management services, radio stations, newspapers, churches and so on. All of these pillars enjoy the same public privileges, subject to exactly the same statutory stipulations ${ }^{3}$ (Sturm et al., 1998).

Each citizen enjoys the freedom to decide for him-/herself about the religious identity of the school which their child attends. They freely decide for themselves whether they wish to place their child in this or that school, each with its own institutional religious/confessional

3 Despite these measures, Dutch society is not entirely peaceful and strife-free, as can be observed in the newspapers (cf. also Dijkstra et al., 1997; Van Deursen, 2005). 
identity, ranging from orthodox reformed-Christian through Catholic and liberal to Orthodox-Muslim, liberal-Muslim, transcendental-meditation, Red Cross and Plato school pillars, to mention only a few 4 (Miedema \& Vroom, 2004:8). The state does not decide on behalf of the citizenry whether some schools should be public and therefore publicly funded, and others private or independent (as in South Africa). The state does not prescribe a school's institutional religious, confessional or life-conceptual identity and the role that religion should play in a particular school and its programmes. Parents can freely decide for themselves what they want in terms of their dual education system (particular and public) and still enjoy equitable state funding (cf. Netherlands, Section 54 et seq. for the funding of public schools, and Section 124 et seq. for the funding of particular or private schools).

Germany uses a hybrid structure. In eight of its federal states, religious education in schools is divided for Catholic, Protestant and for the minority of Muslim learners. The state, the parents as well as their religious denominations have a say in the type of confessional religious education offered in a particular school. In the ninth state, the federal city-state of Hamburg, only one form of religious education is offered, namely inter-denominational, inter-religious, multireligious or dialogical education. According to Weisse (2003), this approach has been necessitated by the great diversity of religions, faiths, confessions and lifeviews among the two million citizens of the state.

\section{The post-2003 South African approach}

What has just been described with reference to the Dutch and the eight German sub-systems is foreign to the educational situation in (for instance) the Republic of South Africa, the United States of America, South Korea and the federal state of Hamburg (Germany). Since 1996, when the Constitution of the Republic of South Africa was promulgated (Act 108 of 1996), it was hailed as one of the most progressive in the world. The inclusion of a Manifesto of Human Rights (Chapter 2 of the Act) was particularly welcomed in view of the apartheid past of the country. As indicated above, a whole surfeit

4 There has of late been a tendency towards further differentiation within pillars, e.g. different kinds of Catholic schools within the Catholic pillar. The "pillars" are in effect becoming smaller and therefore more in number, a circumstance that tends to place much more emphasis on the institutional identity of each individual school. This is a function of the growing diversity in Dutch society. 
of legislation followed the promulgation of the Constitution for purposes of reforming the apartheid state into a liberal democracy. In terms of the new Constitution, the Higher Education Act (101 of 1997) as well as the South African Schools Act (84 of 1996), institutions that wished to have a specific religious, confessional or life-conceptual institutional identity, had to become private or "independent". As such, they are not funded as if they were part and parcel of the public sector. The South African Norms and Standards for School Funding document (RSA, 1998) therefore distinguishes between "Public Funding of Public Schools" (Section 4) and "Subsidies to Independent Schools" (Section 6). Whereas in the Netherlands the latter are being funded as an integral part of the entire system, in South Africa they may be considered for subsidies, depending on the extent of compliance with certain requirements.

The South African state, in the form of the Government of the day, tends to be prescriptive with respect to every aspect of education. This can possibly be ascribed to the fact that the state authorities, in the form of the national Department of Education, has set itself the task of eliminating all possible causes of strife within the citizenry. One of its measures was the banning in 2003 of all forms of confessional religion to the private sphere (RSA, 2003). As indicated, public schools may focus only on teaching religion as an academic subject and provide opportunities for the equal, free and equitable practising of religious observations. 5

What do all of these measures tell us about the degree of secularism in South African education?

- South Africans have only recently (1994) come out of an age of struggle (against apartheid) and some of them have not yet overcome their wariness of other religions;

- South Africans therefore still need the state to remove all possible causes of strife, such as religious affiliation, by following the secularist strategy of relegating them to the private sector;

- this de facto privatisation of religious and ethical values (i.e. to the parental homes, churches, mosques, temples, synagogues and so on) may have contributed to the high levels of crime and violence. In Colditz's (2008:8) opinion, the violence and general

5 School premises and facilities may be made available for this on an equal and equitable basis (RSA, 2003). 
indiscipline prevailing in South African schools today could be a reflection of what is occurring in the broader society. In an effort to address this problem, the Ministry of Education recently contemplated the introduction of a formal pledge that learners would have to recite in schools, as well as a Bill of Learner Responsibilities; 6

- the so-called Laicité philosophy 7 that underpins the educational systems of (for instance) France and the United States of America is regarded as the best for the as yet immature citizenry of South Africa. In other words, citizens need to live in two separate life-domains in the hope that that will remove all causes of strife from the public domain;

- the fact that most South Africans, by far, belong to religious affiliations is of no significance. They have to be satisfied with public schools and other institutions with no apparent religious affiliation apart from the religion of secular humanism, or alternatively face the burden of a double tax in private/independent schools. 8

The upshot of this secularist approach is that of the 27000 schools in South Africa, 24974 are today supposedly life-conceptually neutral public or state schools, and the rest (only approximately 4\%) of them private or independent (Colditz, 2008:2). Most of the latter are associated with some or other religious denomination. Public or state school parents and school communities tend to leave the fate of the schools in the hands of the state and its apparatuses, which in many respects does not possess the skills for the efficient running of schools. Only about $10 \%$ of these schools can therefore today be regarded as functional, according to Colditz. The relatively small number of private or independent schools are functional and efficient because of the constant involvement of all the stakeholders.

The banning of all forms of confessional religion and ethics as stipulated in the Policy on Religion in Education (RSA, 2003, sections 54 et seq.) has taken place despite the fact that both the

6 To date not much has come of these plans, probably because of accusations that Government was planning to indoctrinate its school-attending citizens by means of these machinations.

$7 \quad$ I.e. the strict divide between the public and private sectors as well as between the "secular" and the "sacral" realms of life.

8 Payment of official tax as well as the private or independent school fees. 
Constitution (section 15) and the SA Schools Act (section 7) guarantee freedom of conscience and religion in public schools. The condition, however, is that such religious observances are conducted on an equitable basis, and attendance by learners and staff is free and voluntary. 9 The banning is also a deviation from a position taken in a White Paper (RSA, 1995), namely that parents had the inalienable right to choose the form of education they deemed best for their children, irrespective of whether it is provided by the state or not. This right to choose also included the religious foundations of such education (RSA, 1995:21, 75).

According to the Policy on Religion and Education (RSA, 2003), however, parents and learners do not enjoy the freedom of choosing which schools they will support and attend. They are expected to place their children in schools where they can learn to become religion and diversity literate, and get along with others right from the outset. This necessitates the absence of all forms of confessional religious education in public schools.

\section{Is there another solution?}

Whereas the Dutch education system is comprised of a (steadily increasing) number of school pillars and the current South African education system is comprised of only two de facto school pillars (public and independent), it can be contended that in a true democracy there should be no such pillars along religious fault lines. Learners of all religions should be able to go to one and the same school. At the same time, secularism should have no place in a true democracy. How can this be achieved?

According to a recent Ipsos-Markinor survey (2008), if South Africa were a village comprising of a hundred inhabitants, 73 of them would be Christians. Of this number, 52 would belong to Protestant or Catholic churches, and the other 21 would belong to the Zion Christian Church/the Church of Shembe or another African Independent Church. Slightly more than two would be Muslims, around two Hindus. The rest of the population would belong to indige-

9 On 31 August 2009, Advocate Paul Colditz, the Chief Executive Officer of the Federation of South African School Governing Bodies, stated on the radio station RSG that school governing bodies still tended to determine their own policies on religion based on the stipulations of the Constitution and the SA Schools Act (RSA, 1996a; 1996b), since they regarded the Policy on Religion in Education as in contravention with these two acts. 
nous/animist/other religions (Tellinger, 2006:257). South Africa is therefore a truly multi-religious society. This religious diversity will also be reflected in the educator and learner populations of the schools, but the location of a particular school will determine its unique religious demographics. How does one accommodate this religious diversity in a school without either banning confessional religious education from the school or running the risk of religious conflict within schools? How can one accommodate the religious diversity in schools without on the one hand resorting to the Dutch system of pillarisation which results in keeping learners belonging to different religious affiliations apart in different pillars, or on the other hand resorting to the secularist dualistic approach currently followed in South Africa (public and independent schools)? Strietman (2005: 19 ) is correct in saying that a true democracy functions on the basis of unprejudiced respect for the differences among people and their motives, whether secular or religious, and that these differences cannot be hidden away in the little cubicles of their particular (separate) existences (emphasis - JLvdW).

The notion of institutional identity seems to be key to the solution. Institutional identity, in brief, refers to the religious, confessional and life-conceptual orientation of a school and the manner in which it informs, shapes and influences the pedagogical culture of the school (Bakker, 2004:101; De Wolff, 2000; De Wolff et al., 2002; 2003; Van der Walt, J.L., 2007). All definitions of institutional identity seem to have two elements in common: identity is that which makes an institution such as a school unique in itself, and that which makes it different from all other similar institutions (Van der Walt, J.L., 2007:182).

Parents (of especially small children) should enjoy the freedom to choose for themselves a school whose institutional identity would be most amenable to their personal faith and religious or spiritual convictions. After having established a firm faith base10 in and for the learners, the school should enable them to reach out to others in the school belonging to different faiths, denominations, religions or spiritual traditions. For this second step to be successful, a person obviously needs to be religion and diversity literate. This interaction with adherents of other religions consists of two phases, as Abdool et al., (2007:554-556) recently showed. The first phase is the in-

10 Referred to below as the "truth/Truth", a prerequisite for tolerance of others and their religious views. 
formation exchange phase, during which children are led to become acquainted with the hard facts of all the religions represented in the school itself, and in the broader South African society. The second phase comprises engagement with others at the deepest spiritual level. The purpose of this second phase is to gain comprehension of the other's concept of spiritual meaning, of the other's deepest spiritual convictions. This inter-religious dialogue, interaction and engagement should not only help the participants understand and accept the differences among themselves, but should also have the potential of binding them all together as citizens of the same political unit (such as the South African nation). Of course, as Matsaung (2003:81) found, the success of this process depends on the availability of well-resourced classrooms and well-trained educators who will be able to guide the learners through all the pitfalls of potential religious conflict.

According to Abdool et al. (2007:555), a learner should be sufficiently mature to be able to meaningfully engage with (the adherents of) other religions. It is not pedagogically justifiable to expose a small child to other traditions before he/she has been steeped in the tenets of his/her own religious tradition. 11 It would only lead to confusion in their young minds, and will be contra-productive. A child's proper understanding of his/her own religious tradition will lead to a more favourable understanding of others as well. 12

The European Ministers of Education (2003: section 11) correctly declared that "managing diversity is not a problem in schools alone, but concerns the whole of society, particularly with regard to policies implemented in the social, family and migration fields". Especially for small children, the religious environment should be as homogeneous as possible in order for the teaching-learning process to proceed unencumbered by religious and spiritual tensions. To expose a small child to the religion and diversity literacy approach right from the outset as argued by Weisse (2003:207-208) would therefore not be pedagogically justifiable. This explains why, for instance, Roux and Du Preez (2005:279) found that, despite the enforcement of official policy, in some South African schools a "confessional ap-

11 The truth foundation referred to in footnote 10.

12 Besides this, schools are teaching-learning institutions, not in the first place "germ cells of societies (where) children and adolescents can learn from a model to live together" (the words of a German Muslim mother, quoted by Weisse, 2003:191). 
proach, especially in the Abrahamic religions, may occur. This approach manifests mainly within Christian denominations". Parents in Norway also successfully challenged the system of a compulsory school subject that teaches Christianity, other religions and secular worldviews on an equitable basis. They also used the argument of the identity confusion that their children would be suffering as a consequence of such a religion and diversity literacy program (Hagestaeter \& Sandsmark, 2006:278). As children grow older and become religion, life-conceptually and diversity literate, they can and should be allowed greater freedom for interaction with adherents of other faiths.

The approach just outlined is in line with the United Nations' Declaration of Human Rights (UN, 1948), which declares the freedom to manifest one's own religion or belief in school education as a basic right (section 18). The United Nations' Convention on Civil and Political Rights (UN, 1966) also stipulates that parents have the liberty "to ensure the religious and moral education of their children in conformity with their own convictions" (sub-section 81.4).

According to Ter Avest (2008:9), this approach does not only recognise the confessional differences among people and groups in schools, and does not only prepare small children for contact with adherents to other religions but also educates more mature learners for religious and diversity literacy, for citizenship education in a changing social environment. Thiessen (quoted in Jansen, 2008:15) agrees with her in saying that such "religious schools" rather than neutral schools can contribute to social cohesion. Religion and lifeconceptual literacy is required for learners and adults to explore all the differences among people living together, each after his or her own religious/confessional/life-conceptual tradition, in order to be able to appreciate how they are more alike than they might originally have supposed. The phrase in italics refers to pedagogical freedom in terms of institutional (school) identity, also in the context of growing "glocal" diversity.

This brings us to another perspective presented by Van der Walt (B.J., 2007:201-210), namely how to achieve religious tolerance. He concurs with the conclusion drawn above: even when one believes in the uniqueness of one's own faith, one still has to live daily among a variety of other religions. The question is: How? After a discussion of various forms of tolerance, including "truth without tolerance", "tolerance without truth" he arrives at the most appropriate formula: "tolerance based on Truth", exactly what has been proposed above. A Christian educator, whether parent or teacher, can only base 
tolerance of other religions and their adherents on Truth with a capital T, in other words, for Christians God's infallible revelation. The Bible, as God's Word-revelation, teaches that both religious conviction in Biblical Truth and tolerance of other religious views are possible. Being convinced of Biblical Truth is the foundation of tolerance. Van der Walt (B.J., 2007:212) quotes the following poignant words from Marshall (1991:8):

(Tolerance) means letting others exist freely while seeking when necessary to oppose them by word. It means dealing with our religious differences by the sword of the spirit, not the sword of the state.

According to Thiessen (Jansen, 2008:15), tolerance can only be expressed in terms of relations. Tolerance therefore presupposes outreaching: the willingness to develop relationships with people holding different views that have to be tolerated. Tolerance, according to Kotzé and Du Toit (2006), is as important as trust for the building of social capital, and therefore for civil society. The accrual of trust does not mean that a civic community will be entirely conflictfree, for the citizens of a democracy have strong views on public issues, but they will be tolerant of their opponents. Without tolerance, there will be no widespread contestation, an essential ingredient of democracy. Because of the deep divisions among South Africans, tolerance along the lines demarcated by Van der Walt above will not be possible in the short term, which explains why it has to be entrenched in law.

\section{Recommendations and conclusion}

Given the long history of the dualistic public-private Laicite philosophy in well-established democracies such as France and the United States of America, it would be futile to hope that the democracy in South Africa would mature in the short term to the levels described in the previous section. Several steps to rectify the situation should, however, be considered. Firstly, all schools should be declared state-funded institutions in order to place them in a position to go ahead with their core work, namely teaching-learning, and to save them from spending time and energy on searching for funds. Secondly, each of them should be expected to define its own institutional (religious/life-conceptual) identity so that parents, teachers and learners can know which of them to associate with. Thirdly, each citizen should enjoy the freedom of association with the school of his/her choice. Fourthly, each school should enjoy the freedom of determining its own policy on religion, especially with respect to the 
confessional aspects. Fifthly, each school should take special measures to steep the young learners in the precepts of their respective own (home) religions, and finally, each school should take special measures to guide the older and more mature learners in engaging with other religions and their adherents. Special attention should be given to the inculcation of tolerance of others and their religious differences. This tolerance should be based on what each of the learners sees as "the" Truth for him/her. ${ }^{13}$ Each school has to fill the values that it adheres to with lifeview content. In the case of a school with a reformational institutional identity, such content will flow from the Truth as embodied in the Bible as the inscripturated Word of God.

The secular public-private/worldly-sacred dualisms inherent in the Laicité approach has no place in the approach just outlined. Parents, teacher-educators and learners will all live their lives as total and integrated persons in and with respect to their schools; the need for relegating all forms of confessional religion to the private sphere of their lives will have dissipated. And finally, because of enjoying the privilege of living in a (rather more) mature democracy, South Africans need not fear the differences prevalent in the growing diversity of their society because they enjoy opportunities for maturing in religious and diversity literacy as a prerequisite for engaging other religions/faiths and their adherents. In other words, they have learnt to understand, tolerate and get along with others belonging to different faiths and religious convictions. They have also learnt to respect religious and confessional difference in the context of diversity and pluralism, a condition that is on the increase worldwide (Goodstein, 2005; Westerman, 2004:1; Cocks, 2007; Pigott, 2007; Hitchens, 2007). Social cohesion can be promoted by developing tolerant behaviour; it cannot be promoted by pressing all people into the same religious (i.e. secular) frame of mind (Thiessen quoted in Jansen, 2008:15).

13 Tolerance should not be based on a set of values that is largely devoid of lifeconceptual content (Swartz, 2006; Zecha, 2007) such as we currently have as guiding lights for education in South Africa: democracy, social justice and equity, equality, non-racism and non-sexism, ubuntu (human dignity), an open society, accountability (responsibility), the rule of law, respect and reconciliation (Ministry of Education RSA, 2001). None of these values has any religious or lifeview content. Justice, for instance, only gains meaning when interpreted from a specific religious or lifeview perspective. Justice in a Biblical context differs from justice in a pragmatic, secular context. 


\section{List of references}

ABDOOL, A., POTGIETER, F., VAN DER WALT, J.L. \& WOLHUTER, C. 2007. Inter-religious dialogue in schools: a pedagogical and civic unavoidability. Reformed theological studies, 63(2):543-560.

BAKKER, C. 2004. Hoe geef je vorm aan de identiteit van de school? (In Miedema, S. \& Vroom, H. Alle onderwijs bijzonder. Zoetermeer: Meinema. p. 97-124.)

BEHR, A.L. 1984. New perspectives in South African education. Durban: Butterworths.

CHOPRA, D. 2009. The third Jesus: how to find truth and love in today's world. London: Rider.

COCKS, T. 2007. Pentacostalism embraced as a cure for Africa's many ills. Weekend post: 7, 30 Jun.

COLDITZ, P. 2008. 'n Perspektief op die werklikhede van skoolonderwys in Suid-Afrika. Voordrag gelewer by die Algemene Sinodale Moderamen van die NG Kerk, Benoni, Suid-Afrika, 20 Aug.

DE KLERK-LUTTIG, J. \& VAN DER WALT, J.L. 2008. An educational strategy for combating moral degeneration in South African society. Nederduitse Gereformeerde teologiese tydskrif, 49(3 \& 4):113-123, Sept. \& Dec.

DE KNIJFF, H.W., DEKKER, G. \& TENNEKES, J. 1992. Christelijke waarden in een geseculariseerde cultuur. Amsterdam: VU-uitgeverij.

DE WOLFF, A. 2000. Typisch Christelijk. Kampen: Kok.

DE WOLFF, A., DE RUYTER, D. \& MIEDEMA, S. 2003. Being a Christian school in the Netherlands: an analysis of "identity" conceptions and their practical implications. Journal of beliefs and values, 24(2):207-217, Aug.

DE WOLFF, A., MIEDEMA, S. \& DE RUYTER, D. 2002. Identity of a Christian school: conceptions and practical significance. A reconstructive comparison. Educational review, 54(3):239-247.

DIJKSTRA, A.B., DRONKERS, J. \& HOFMAN, R. 1997. Verzuiling in het onderwijs. Groningen: Wolters-Noordhof.

EUROPEAN MINISTERS OF EDUCATION. 2003. Declaration on intercultural education in the new European context. 21st Session of the Standing Conference of European Ministers in Education. Athens, Greece, 10-12 Nov.

FERGUSON, R. \& ROUX, C. 2004. Teaching and learning about religions in schools: responses from a participation action research project. Journal for the study of religion, 17(2):5-24.

FÖRRER, M. \& VAN HARDEVELD, G. 1992. Een onderwijsbestel met toekomst, 1919-1992. Amersfoort: Christelijk Pedagogisch Studiecentrum.

FOWLER, S. 1991. A Christian voice among students and scholars. Potchefstroom: IRS.

FOWLER, S. 2001. Contours of a transformational scholarship. (In Kok, J.H., ed. Marginal resistance. Sioux Center: Dordt College. p.129-152.)

GOODSTEIN, L. 2005. From mosque to steeple, faith rises. The New York times: 1 \& 4, 23 Jan. (Articles selected for the South African Sunday times.)

HAGESTAETHER, G. \& SANDSMARK, S. 2006. Compulsory education in religion - the Norwegian case: an empirical evaluation of RE in Norwegian schools, with a special focus on human rights. British journal of religious education, 28(3):275-287. 
HITCHENS, C. 2007. Religion poisons everything. The Sunday times: 29, 20 May.

IPSOS-MARKINOR. 2008. Freedom Day in South Africa. 9 May. E-mail to: mari.harris@ispsos.markinor.co.za

JANSEN, L. 2008. Het verband tussen verbondenheid, verscheidenheid en verdraagzaamheid. DRS magazine, 36(1):14-16, Jan.

KOTZÉ, H. \& DU TOIT, P. 2006. Civil society. (In Van Beek, U., ed. Democracy under construction. Pretoria: Van Schaik. p. 243-258.)

KRUGER, P.P. 2009. Godsdiens in openbare skole ... ja en nee. Die Kerkblad, 112(3229):10-12.

MARSHALL, P. 1991. Overview of Christ and culture. (In Van der Vennen, R.E., ed. Church and Canadian culture. Lanham: University Press of America. p. 1-10.)

MATSAUNG, L.E. 2003. The teaching of religious education in multi-religious classes: is it a problem to students? Educational research, 45(1):79-82.

MIEDEMA, S. \& VROOM, H. 2004. Alle onderwijs bijzonder: ter inleiding. (In Miedema, S. \& Vroom, H. 2004. Alle onderwijs bijzonder. Zoetermeer: Meinema. p. 7-18.)

NETHERLANDS, The. 1920. Primary school Act of 1920. Den Haag: Government of the Netherlands.

NETHERLANDS, The. 1983. Constitution of the Kingdom of the Netherlands. Den Haag: Government of the Netherlands.

PIGOTT, R. 2007. Religious education - warts and all. The Herald: 6, 22 Jun.

ROUX, C. 2003. Playing games with religion in education. SA journal of education, 23(2):130-134, May.

ROUX, C. 2006a. Children's spirituality in social context: a South African example. International journal of children's spirituality, 11(1):151-163, Apr.

ROUX, C. 2006b. Innovative facilitation strategies for religion education. (In De Souza, M., Engebretson, K., Durka, G., Jackson, R. \& McGrady, A., eds. International handbook of the religious, moral and spiritual dimensions in education. Part 2. Dordrecht: Springer. p.1293-1306.)

ROUX, C. \& DU PREEZ, P. 2005. Religion in education: and emotive research domain. Scriptura, 98(1):233-374.

RSA

see SOUTH AFRICA

SCHUTTE, B.C. 1984. Christelike onderwys in 'n moontlike stelsel van religieuse en lewensbeskoulike differensiasie in die RSA. Potchefstroom: Departement Fundamentele Opvoedkunde.

SINCLAIR, J.M., ed. 1999. Collins Concise Dictionary. Glasgow: HarperCollins.

SOUTH AFRICA. 1995. Onderwys en opleiding in 'n demokratiese Suid-Afrika: eerste stappe om 'n nuwe stelsel te ontwikkel. Witskrif 1, 15 Mar.

SOUTH AFRICA. 1996a. Constitution of the Republic of South Africa (84 of 1996). Pretoria: Government Printer.

SOUTH AFRICA. 1996b. The South African Schools Act (84 of 1996). Pretoria: Government Printer.

SOUTH AFRICA. 1997. The South African Higher Education Act (101 of 1997). Pretoria: Government Printer.

SOUTH AFRICA. 1998. National Norms and Standards for School Funding in terms of the South African Schools Act (84 of 1996). Pretoria: Department of Education. 
SOUTH AFRICA. 2001. Manifesto on values, education and democracy. Pretoria: Ministry of Education.

SOUTH AFRICA. 2003. Policy on Religion in Education. National Education Policy Act (27 of 1996). Pretoria: Government Printer. (Government Gazette, 459(25459), 12 Sept.)

STRIETMAN, H. 2005. Alle onderwijs werkt aan waarden: ook die openbare school bijzonder. SBM-maandblad van de besturenraad voor managers, bestuurders en toezichthouders, 8:18-19.

STURM, J., GROENENDIJK, L., KRUITHOF, B. \& RENS, J.A. 1998. Educational pluralism - a historical study of so-called "pillarization" in the Netherlands, including a comparison with some developments in South African education. Comparative education, 34(3):282-297.

SWARTZ, C. 2006. A long walk to citizenship: morality, justice and faith in the aftermath of apartheid. Journal of moral education, 35(4):551-570, Dec.

TELLINGER, M. 2006. Slave species of god. Johannesburg: Music Masters.

TER AVEST, I. 2008. From the teacher's knee: chances and hindrances for religion in the classroom. Paper read at Conference on Religion, Spirituality and Education. Driestar Educatief, Gouda, 15-17 Jan.

UN

see UNITED NATIONS

UNITED NATIONS. 1948. Declaration on Human Rights. New York: United Nations.

UNITED NATIONS. 1966. Convention on Civil and Political Rights. New York: United Nations.

VALENKAMP, M. 2008. The spiritual and religious dimension of education and bringing-up. Koers, 73(2):323-348.

VAN DER WALT, B.J. 2007. Transforming power: challenging contemporary secular society. Potchefstroom: Institute for Contemporary Christianity in Africa.

VAN DER WALT, J.L. 2007. Formalizing institutional identity. (In Aspin, D.N. \& Chapman, J.D. 2007. Values education and lifelong learning. Dordrecht: Springer. p.180-198.)

VAN DER WALT, J.L., WOLHUTER, C.C. \& POTGIETER, F.J. 2008. Die intrinsieke verband tussen opvoeding en spiritualiteit. Koers, 73(1):1-14.

VAN DEURSEN, A.T. 2005. Een hoeksteen in het verzuild bestel - de Vrije Universiteit. Amsterdam: Bakker.

WEISSE, W. 2003. Difference without discrimination: religious education as a learning field for social understanding? (In Jackson, R., ed. 2003. International perspectives on citizenship, education and religious diversity. London: Routledge-Falmer. p. 191-208.)

WESTERMAN, W. 2004. Godsdienst komt terug in het publieke domein. Nieuwsbrief: Hendrik Piersonleerstoel, 11(1):1, Jan.

WNUK-LIPINSKI, E. \& FUCHS, S. 2006. Theoretical framework and methodology. (In Van Beek, U., ed. 2006. Democracy under construction. Pretoria: Van Schaik. p. 39-62.)

WOLHUTER, C.C., VAN DER WALT, J.L. \& POTGIETER, F.J. 2009. The South African policy on religion and education: its potential to create social capital. Journal of religious education, 57(1):38-47.

ZECHA, G. 2007. Opening the road to values education. (In Aspin, D.N. \& Chapman, J.D. 2007. Values education and lifelong learning. Dordrecht: Springer. p. 48-60.) 


\section{Key concepts:}

diversity literacy

education

institutional identity

religion

schooling

secularism

\section{Kernbegrippe:}

diversiteitsgeletterdheid

godsdiens

institusionele identiteit

opvoeding

religie

sekularisme

skoolonderwys 